\title{
BEWARE THE GREAT HORNED SERPENT: INSURGENCIES IN CHIAPA IN 1812 AND CHIAPAS, 1994
}

\author{
Robert M. Laughlin
}

National Museum of Natural History

Smithsonian Institution, Washington, D.C.

\begin{abstract}
Resumen: En 1812 la regencia de Cádiz envió una proclama a los colonizadores en la que urgía su lealtad en la guerra contra Napoleón, y advirtiéndoles de los beneficios que recibirian con la nueva Constitución. Éste fue, al parecer, el único edicto español enviado con instrucciones de traducirlo y publicarlo en lenguas indigenas, según el espíritu liberal de los diputados a las Cortes. El gran respeto de la proclama hacia los indios contrasta finamente con su posición en el Nuevo Mundo, donde unos cuantos colonizadores ilustrados luchaban contra los poderes racistas de la Iglesia y el Estado. Una traducción anónima de un fraile al tzotzil-tzeltal, llena de metáforas nativas, convirtió a este documento político en una apología de la moralidad. No se sabe si sus palabras fueron escuchadas alguna vez por los indios. Existen coincidencias sorprendentes entre la situación en Chiapas en 1812 y en 1994: económica, social, política y religiosamente; la metáfora mágica todavía está mucho muy viva.
\end{abstract}

ABstract: In 1812 the Regency of Cadiz sent a proclamation to the colonists urging their loyalty in the war with Napoleon, and advising them of the benefits they would receive under the new Constitution. Reflecting the liberalism of the deputees to the Cortes, this is apparently the only Spanish edict ever sent with instructions that it be translated and published in native languages. The proclamation's high regard for Indians contrasted sharply with their position in the New World, where a few enlightened colonists struggled against the racist power of Church and State. An anonymous friar's Tzotzil-Tzeltal translation, filled with native metaphor, converted this political document into a plea for morality. It is not known whether its words were ever heard by the Indians. There are surprising parallels between economic, social, political, and religious situations, in Chiapas in 1812 and 1994; magical metaphor is still very much alive.

Ya sabeis pasan hoy cinco años que vino de otra distinta region un mal hombre, un desconocido matador Napoleon se llama; se hizo engañador; se hizo nuestro proximo, nuestro allegado, y viniendo entró en nuestra Nación como serpiente que trae puesta una engañosa máscara en el rostro. ${ }^{1}$
En el principio solamente manifestó en su boca buena composicion ó razonamiento de palabra que lo dió en audiencia la bondad de sus obras solamente manifestó en rostro como semblante de nuestros hermanos, $y$ después nos engañó, nos lastimó, nos aborreció, nada bien correspondió á la bondad de nuestras obras en su favor. ${ }^{2}$

\section{${ }^{1}$ Sotzil: 3 . \\ ${ }^{2}$ Ibid., 5.}

Estudios de Cultura Maya. Vol. XXI, 2000

Instituto de Investigaciones Filológicas/

Centro de Estudios Mayas, UNAM 
El matador Napoleón, asi como gran tigre, quiso meternos en su mortal boca se sentó su substituto en la gran ciudad Madrid se llama: asi como viento arrasador trastornó a nuestro amo ó Sor. Rey: con injusticia ó debalde solamente lo amarró al principio: piso sus benditos preceptos, y llamando lo llevó a la cárcel. ${ }^{3}$

Asi como encendido fuego ya acaba Napoleon todas las cosas: despues ya arrebata, ya mata ya borra otras ciudades, otros pueblos divisando vino el camino, y las dos grandes columnas de Hércules se llaman como demostraciones de la ciudad de Cádiz. Ya agarré esta gran tierra dice Napoleon, ahora yo soy su dueño ó poderoso del Universo, asi grita su malicia: asi charla la boca de la espia, y matadores. ${ }^{4}$

I will attempt to capture a portrait of history in the most insignificant representations of reality, its scraps as it were, calling on Napoleon to introduce to you a serpentine tale that wound through my life for many years and still on the advance. This adventure story began for me nearly 20 years ago when my colleague, Jane Walsh, who was working in the National Anthropological Archives, thrust a batch of papers in my hands. "Do you know anything about this Manuscrito en lengua sotzil?' It was a document typed by William Gates, formerly Director of the Middle American Research Institute at Tulane University, that he identified as a Tzotzil translation of a Spanish proclamation of 1812. He comments,

The present proclama is one of my "red mark" mss, for all reasons - the scantiness of the material, its translation, and notes, and also its wholly unique character as a Napoleonic document. I know nothing like it in any dialect. It is a translation apparently into that far-off native minor dialect of the appeal for aid against Napoleon issued from Cadiz by the Junta, and throws a most interesting light on the situation at that time. So though my $\mathrm{ms}$. is only a modern copy of the $1813 \mathrm{~ms}$. (where the original is I don't know), it stands also at the very top in interest. ${ }^{5}$

So, aided by the Spanish text, I set about to transcribe this very strange version of Tzotzil, using our contemporary Tzotzill alphabet.

Packed with metaphors, it was clear that the Spanish text could not have been the original form of the proclamation. I searched diligently in the stacks of the Library of Congress, but with no luck. So, I had to take my family on the S.S. Leonardo da Vinci to Spain.

For 2 weeks I searched in every library in Madrid. Armed with a letter of introduction from the American Cultural Attaché, I rapped on the massive wooden door of the Duque del Infantado, whose ancestor had signed the proclamation. An ancient hag opened the door a chack to tell me that the Duke was on his yacht.

Finally, in one of the libraries I discovered a biography of a Colombian prominent in the Cortes of Cadiz who had drafted the proclamation. The author was on vacation, too, but after a phone call, intrigued by my mission, he arranged for me to visit his apartment behind the bullring, so that I could search through his library. There I found a book by a deputy to the Cortes, languishing in jail, who wondered how Don Joaquín de Mosquera y Figueroa, could be his judge, he who wrote - And then followed a single paragraph from the proclamation.

I headed then to the archives in Seville where I could never retie the bundles to their satisfaction. I found nothing. Nor in Cadiz. So I returned home sadly but with a paragraph.

\footnotetext{
${ }^{3}$ Ibid, 11.

4 Ibid, 13.

5 Gates: Memorandum list $\mathrm{n}^{2} 7$ sent to Charles Bowditch 1915?
Estudios de Cultura Maya. Vol. XX1,2000

Instituto de Investigaciones Filológicas/

Centro de Estudios Mayas, UNAM

ISSN: 0185-2574
} 
A week later I returned to the Library of Congress stacks and randomly pulled out a book, and opened it: Proclama del Duque del Infantado a los habitantes de ultramar! There it was, embedded in a collection of documents in the archives of Guatemala. I translated it and, filled with joy, sent it to my father who returned it with the note, "A very repetitious and pompous proclamation."

Undaunted, I sought to discover the translator. If anywhere, his identify would be found in the cathedral archives of San Cristobal de Las Casas. No archivist existed then. Just a spooky room piled with stacks of dusty bundles of parchments and papers crawling with worms, the remnants of the great archive assembled by Bishop Orozco y Jiménez where shortly afterwards, the Carranza army, after tossing the contents into the street, had stabled its horses. Day after day I untied every bundle with no luck at all, until I came upon the correspondence of Bishop Ambrosio Llano, hundreds of latters in neat chronological order. There I learned the names of two friars who regretted that despite the importance of explaining the worthy points of the Proclamation to the Indians, they were too old and infirm to translate such an elevated proclamation. Nothing more.

I decided to put off further work on it, till my old age. Several years passed and then one day I was visited by Lawrence Feldman who had just returned from Seville where he had discovered translations into four Indian languages of a proclamation. "Signed by the Duque del Infantado?" "Yes!" Three of them had been submitted by the Archbishop of Guatemala. One was K'ekchi', one, Ixil, and the third Zeefe. I phoned Terrence Kaufman who told me to read a bit out of the last and also of the unidentified translation. As I stumbled along Terry said, "I thought you were experienced in reading colonial Maya texts!" "Well, l'll send them along and you read them!" A week later, a bit sheepishly he reported that the first was the longest existing text of the extinct language, Xinka, and the second was Quechua.

With a clue from Bruce Mannheim, who identified the Quechua as beig the Cuzco dialect, I discovered a bibliography containing the proclamation and a cover letter from the Archbishop of Lima who referred to "el n. 121, contexté por el Ministerio de Despacho de V. E. que luego que se hiciese la traduccion e impresión de la Proclama a los habitantes de estos reynos, remitiria exemplares de ella por triplicado como se me previno de orden de S.A.S. de 30 de Agosto del año pp.do." ${ }^{6}$ The bibliographer, Paul Rivet commented, "Because of its historical interest and rarity we reproduce in full the text of this proclamation." ${ }^{7}$

Despite my father's opinion, this Spanish proclamation is a model of conciseness. Sent to all the colonies of America and Asia, it was a valiant effort to restore Spain's hegemony, but shortly after its issuance absolutism under Fernando VII returned with a vengeance. It became an irrelevant, forgotten document. I could find no copy in Spain. Now I only kwow of copies in the archives in Seville, Guatemala City, Lima, Mexico City, and several that I finally found in the church archives in San Cristobal that are now lost. I only know of five books that give it a mention; two bibliographies, two biographies, and the plea written by the jailed deputy. It is likely that it, as the Constitution itself, promoted a demand for liberal government throughout the colonies, establishing a mind set that would no longer tolerate abuse, contributing to the revolu-

\footnotetext{
${ }^{6}$ Rivet, 1951: 257.

7 Ibid.
}

Estudios de Cultura Maya. Vol. XXI, 2000

Instituto de Investigaciones Filológicas/

Centro de Estudios Mayas, UNAM

ISSN: 0185-2574 
tionary cause, to the irresistible desire for independence.

All pertinent royal decrees were routinely sent to both the civil and religious governments. But the destruction of their archives in the military turmoils of the nineteenth and twentienth centuries, together with the difficulty of penetrating the surviving church archives, has impeded the discovery of other translations of the proclamation into Indian languages of Mexico and South America, and possibly native languages of the Philippines. With its particular concern for "los Indios, esa preciosa porción de hombres que habita la América," ${ }^{8}$ this proclamation called not only for the colonists' loyalty, but also for a new, national respect for Indians.

These translations emphasize the Regents' intention that Indians be aware of the new order. To my knowledge this is the only Spanish decree ever sent to the Colonies with specific instructions that it be translated and printed in the native languages. By the beginning of the nineteenth century the number of Indians literate in their mother tongue must have been limited, but the elite, both in Peru and in Tlaxcala, did publish texts in their own language. The number of edicts issued by the Viceroy of New Spain, directed in Nahuatl that warned of the perils of following the rebel Hidalgo, indicates that local government considered it appropriate to communicate to the Indians not just in Spanish. Perhaps it was under the influence of the Peruvian deputy to the Cortes, Inca Yupangui, and the Tlaxcalan deputy, who were the most eloquent spokesmen for the Indian cause, that this order for traslation of the Proclamation was promulgated. It may be taken as a reflection of the sin- cerity of the liberal deputies of the Cortes of Cadiz.

The scene in Spain can only be described as true melodrama. After Manuel de Godoy, a guitar-playing street singer, had become Carlos IV's prince of Peace and Queen Maria Luisa's lover, after their son, Fernando VII had tried to poison them, and after Napoleon had tricked both father and abdicate. Joseph Bonaparte, "half philosopher, half king," arrived to create a constitutional monarchy, with a national theatre, an art gallery, Italian opera and ballet, but scornfully balked by his brother at every turn, he became simply Pepe Botellas.

Guerrilla warfare was born. Wellington's army had one success after another, aided by 1,000 gigantic Scotsmen in kilts. Though in one town where every cellar was stocked with casks of wine, his soldiers literally floated in lakes of wine. But a captured French officer confessed to Lord Wellington, "Le fait est, Monseigneur, que vous avez une armée, mais nous sommes un bordel ambulant." The junta of Valencia complainded in a ploclamation that the French "have behaved worse than a horde of Hottentots. They have profaned our temples, insulted our religion, and raped our women."10

There were revolts in Argentina and Venezuela.

Cadiz was the only city in Spain that had not fallen to Napoleon. Under constant bombardment for three years, the port flourished with freedom of the press, 17 newspapers, theatre, a cultural matriarchy of salons and cafe society where they wrote poems and jokes mocking the French. It held a large colony of Latin Americans who bolstered the sympathy of the merchants for the colonists in America.

8 Boletín del Archivo General del Gobierno, 3, 514.

? Stanhope, 1888: 144.

${ }^{10}$ Carr, 1966: 107 Estudios de

Cutura Maya, Vol. XXI, 2000

Instituto de Investigaciones Filológicas/

Centro de Estudios Mayas, UNAM

ISSN: 0185-2574 
To the defense of Cadiz came Manuel Jiménez Guazo, a former official of the Supreme Junta of Seville, who marshalled a band of troops under the name and banner of the Crusades. Bishops and priests exhorted the people to join. They fought tenaciosly, led by their general, wearing the insignia of the Crusades on his chest, an enormous sword at his belt, bearing a Crusades banner, and endowed with a large "dragon-like" moustache. Here was a figure embodying the human and the divine, uniting war and religion, indignant that the young people sarcastically called him Don Quijote.

But most valiant in the defense of Cadiz and Spain was the Scotsman, John Downie, whose legion was dressed in a medieval uniform of scarlet and white doublets, breeches, capes, carrying lances with scarlet and white trim, while he himself bore Pizarro's sword.

As John Downie led his batallion into action, a French bullet pierced one eye, and as he felt himself falling from his mount and surely into captivity, with a mighty effort he heaved Pizarro's sword back to his troops. Abandoned by the French army on the roadside, he made his way back to his batallion and recovered his sword. Returning for the glory of Spain, he rode into Seville, tall, lean, with his long, drooping moustache, and a black patch covering the left side of his face, causing such an uproar among the populace waving banners of welcome from their balconies, that the French soldiers abandoned the city in haste. While he, too, was the subject of jokes, he was also highly esteemed as a brave cavalryman.

If this celebration of tradition seems truly absurd, one had only to witness the national parade in Mexico City on September 16, 1991, when the military vehicles rumbled down the Reforma, equipped with modern weapons of tremendous velocity and firepower, whose names are not even known by the public, sandwiching between them 150 cavalrymen, holding their swords erect, "at the carry," their steeds' rumps trimmed to display a checkerboard pattern. Eight of the cavalrymen carried an eagle on their fists!

For 18 months the deputies labored to create a liberal constitution that was inaugurated with a procession, a Thanksgiving Mass, a Te Deum, a banquet, and fireworks. The Cortes on August 30,1812 issued a proclamation that was motivated by "la consoladora esperanza de poder atraerlos y abrigarlos benignamente en su seno." ${ }^{11}$

In New Spain the Spaniards at the Cabildo were outraged over the Cortes granting Indians and castes the right to represent them in the Cortes. The merchant guid protested vehemently, tarring not only the Indians and castes, but also the Spanish Americans. Here are a few selection from the speech that caused the Americans in Cadiz to attempt a walk-out:

[The pre-conquest Indians were] preocupados con la mas rabiosa supersticion de Ritos y Ceremonias insultantes á la razon y á la naturaleza, de mandamientos malvados absurdos y locos, y de prácticas cuyo conjunto hacia un compuesto abominable de todos los errores y atrocidades que consagró la gentilidad en diferentes partes y tiempos. ${ }^{12}[\ldots]$ envano algunos estrangeros, infatuados por el fanático é hipócrata Casas nos acusan amargamente, y con una villana emulacion, de la mortandad en la conquista. ${ }^{13}[\ldots]$ Por la maravillosa metamorphosis que hayan conocido los siglos, se transformaron Señor, subitamente en hombres domésticos, sugetos á una policia blanda los Orangutans pobladores de las Américas. ${ }^{14}[\ldots][\mathrm{El}$ indio] esta dotado de una

\footnotetext{
${ }^{11}$ Vela, 1968: 66.

12 Hernández y Dávalos, 1877, II: 455.

${ }^{13}$ Ibid., p. 456.

${ }^{14}$ Ibid., p. 457.
} 
pereza y languidez que no pueden explicarse por exemplos. [...] estúpido por constitucion, sin talento inventor, ni fuerza de pensamiento, aborrece los artes y oficios, y no hacen falta á su método de existir: borracho por instinto satisface esta pasion á poca costa con brevages muy baratos y la privacion recibe un tercio de su vida: carnal por vicio de la imaginacion, y desnudo de ideas puras sobre la continencia, pudor ó incesto, provee á sus deseos fugaces con la muger que encuentra mas a mano: tan descuidado en la virtud cristiana, como insensible á las verdaderas religiosas: el remordimiento no turbe su alma, ni detiene sus apetitos pecaminosos. ${ }^{15}$ [...] el indio no propasa actualmente sus ideas, pensamientos, intereses, y voluntad, mas allá del alcance ó termino de sus ojos, y que desprendido de los sentimientos patrióticos, y de toda mira social, solo pide de la autoridad pública, un cura indulgente, y un subdelegado haragán. [...] [Las castas] son de la misma negligencia del Indio, sin embargo de criarse y existir a la sombra de las ciudades en donde forman la clase ruin del populacho. [...] sus ropas son los andrajos y el sol. [...] Un millon de blancos que se llaman Españoles Americanos, muestran la superioridad sobre los otros cinco millones de indígenas, más por sus riquezas heredadas, por su carrera, por su lujo, por sus modales y por su refinamiento en los vicios, que por diferencias substanciales de índole, sentimientos, propension según lo acredita la multitud de blancos sumidos en la plebe por sus dilapidaciones y de profesar las facultades y artes, y de consolarse en la ausencia de sus riquezas con sueños y trazas de la independencia que ha de conducirlos á la dominacion de las Américas. ${ }^{16}$ [...] [Their self-sacrifices] elevan al Español Europeo á la reputacion de Vasallo leal é inseparablemente unido á la Metropoli por los vinculos de la naturaleza, del reconocimiento, y aun del egoismo. Si, Señor, entra tam- bien el egoismo en la composicion de esta fidelidad memorable, pues que la existencia del Europeo corre el riesgo desde el primer grito de la insubordinacion Americana. [...] [La Nueva España es] una Provincia mansion de $5 \mathrm{mi}$ llones de automatas, de un millon de vasallos discolos y de cien mil ciudadanos adictos al orden. ${ }^{17}$

The representative concludes his harangue bassackwards, "El paralelo entre el Español y el Indio ¿no seria una comparacion de una manada de Monos gibones con una asociacion o república de hombres urbanos?"18

In 1809 Baltimore became the seat of Napoleonic intrigue in the Americas, staffed with 50 agents, "Apostles of Bonaparte," "Disciples of Bonaparte," headed by a Mr. Desmolard who lived with great ostentation, decorated livery and a tricolored cockade. But Luis de Onis in New Orleans kept a close watch on the agents and sent their names to frontier officials. In 1810 ten agents were known to be working in Mexico and 4 in Central America. It was these agents' mission to spread the word to the creoles of the U.S. progress in commerce, agriculture, navigation, freedom, and "comforts." In the words of Joseph Bonaparte to his envoy,

The object which these agents are to aim at, for the present, is no other, than that of manifesting to, and persuading the Creoles of Spanish America, that I have solely in view, the gaving of liberty to a people, enslaved for so many years, without expecting any return for so great a boon, other than the friendship of the natives, and the commerce with the harbors of both Americas, ${ }^{19}$

\footnotetext{
15 Ibid., p. 458.

16 Ibid., p. 459.

17 Ibid., p. 462.

${ }^{18}$ Ibid., p. 466.

19 Rydjord, 1972: 290.

Estudios de Cultura Maya. Vol. XXI, 2000

Instituto de Investigaciones Filológicas/

Centro de Estudios Mayas, UNAM 
Referring specifically to the Indians, he adds,

They will also remind the Indians, circumstantially, of the cruelties which the Spaniards employed in their conquests, and the infamies which they committed towards their legitimate sovereigns, by dethroning them; by taking away their lives or enslaving them. ${ }^{20}$ [...] They will, moreover, make the Indians observe, how happy they will be, when they become, once more, masters of their country, and free from the tyrannical tribute, which they pay to a foreign monarch. And lastly, they will tell the people, that their said monarch does not so much as exist in his own government, but is in the power of the restorer of liberty and the universal legislator, Napoleon. ${ }^{21}$

A Baltimore agent wrote and sent a proclamation, "instructing the agents to foments revolution. Creoles were to be reminded of their shameful treatment by Peninsular Spaniards, while Indians were to be told of the dreadful cruelties of the Spanish conquest." ${ }^{22}$

Commenting on one proclamation the Inquisitors expound, "igualmente detestable por su impiedad, como por su ignorancia aun del idioma Castellano, en que nos habla. ${ }^{23}$ The Viceroy concludes that Napoleon "cree que sois tan estúpidos como los mahometanos del Egipto, y $\tan$ frios y helados como los hotentotes." ${ }^{24}$
All this while Morelos was capturing town after town in the south.

Napoleon's "barbarous papers" were duly burned in the main square of Nueva Goathemala and in Nicaragua was discovered skirt material that had on one end "la figura odiosa del abominable tirano de Europa." 25 Captain General Bustamante and the Archbishop sharing the most conservative views, despised the constitution, and sought to maintain an iron-handed rule in opposition to the liberal civil officials of Nueva Goathemala and to the deputies to the Cortes in Cadiz.

In the Province of Chiapa at the end of the 18 th century the Bishop had reported to the King that "Las vejaciones, desnudez, idiotismo de los Indios son por causa de los repartimientos excesivos," ${ }^{26}$ and the Governor complained,

Es el indio un Animal de costumbres que propiamente puede colocarse entre el Mono y el hombre, pues se le observan acciones mui homogeneas a las dos especies; nada hace si no se le manda por el Juez. O el Padre Cura, pues como se contenta con poco y nada ambiciona no le motiva a trabajar....el modo de aplicarle un agente que mueba a su maquina. ${ }^{27}$

The permanent Vicar of Chamula, Joseph Ordóñez y Aguiar, brother of the man credited with discovering Palenque, Ramón Ordóñez y Aguiar, had been accused of "mucho lo assota las Mugeres en su Narcas," 28 and two men had

\footnotetext{
${ }^{20}$ Walton, 1814: III-IV.

${ }^{21}$ Ibid., IV-v.

22 Robertson, 1939: 68.

${ }^{23}$ Hernández y Dávalos, 1877, II: 445.

25 Gazeta de Guatemala, November 6, 1810: xIv (183), 306.

${ }^{26}$ Carta, Polanco a Carlos III, May 20, 1778.

27 Carta, Quetas Zayas a Carlos III, May 2, 1792.

${ }^{28}$ Porrúa, 1992: 136.
}

${ }^{24}$ Proclama del Arzobispo Virrey de México contra los engaños pérfidos de los Bonapartes, Abril 24, 1810, p. 13. 
died from being given 100 lashes. The priest's trials were many. Commenting on the service provided by his porters:

pues no hay duda en que á los Curas nos es gravoso el haver de tratar familiarmente con unos muchachos rusticos, y de agrestes costumbres, aguantarles sus robillos, y otras impertinencias, que ya se harian tolerables si concluida la semana no se fuesen estos, y substuiesen en su lugar otros tan varvaros como acavados de sacar de los Montes [...] el servicio y compania familiar de los Porteros es una de las cargas insufribles, que tenemos de los Curas de los Indios. ${ }^{29}[\ldots]$ pues aquellos, á quienes cicilicé, doctriné y enseñe á leer, y escribir, para utilidad del Pueblo, han usado, y usan de esta de esta avilidad en copiar Peticiones contra $\mathrm{mi}^{30}$

Principally because this priest was determined to catechize the Indians, their leaders rebelled, threatened to kill anyone who spoke to him, threatened to move to Ciudad Real unless he was remoced, and finally forced him to flee.

But not everyone was convinced that the Indians were a totally negative element of society, for in 1801 there appeared in the Gazeta de Guatemala a protest entitled, "Un Ladino ilustrado defiende a los Indios contra los que opinan que ellos son ociosos y borrachos por naturaleza." After describing the Indians' industry and humility, he comments on a report he has seen that claims that the best way to make Indians industrious is to have them wear shoes and western clothes. This report, attracting much attention in Guatemala, was written by Fray Matías de Córdoba, later the prime figure in de- claring Chiapa's independence. The illustrious Ladino objects:

Este autor olvidó lo que debía haber tenido más presente; olvidó que los Indios son entre nosotros los únicos que riegan la tierra con el sudor de su rostro, para asegurarnos un pan que ellos no comen; olvidó que si ellos no trabajaran, lo tendríamos nosotros que hacer para no morirnos de hambre. En conclusión, los brazos de los Indios son los verdaderos cuernos de la abundancia de Guatemala. ${ }^{31}$

From Guatemala came a stream of circulars to the Province of Chiapa warning the people of enemies disguised as priests. All travellers had to carry passports. One spy was described in detail:

Es alto de cuerpo, gueso, llano de cara, bermejo, pelo cortado a la frente, nariz larga, y abultada, ojos grandes azules, patillas hasta la barva. Edad de treinta y cinco años, vestido de Sevita, o fraque de paño celeste de primera con gorrita de pico alto, cinturon negro de lustre laboreado de plata, caballo tordillo flaco herrado de los quatro pies, silla Brida, anquera de paño azul con fleco amarillo. Estribos de plata. $^{32}$

Priests along "el Camino Real desde el Raya al Nueva España y Tabasco" were advised to alert the people. There would be a reward of $\$ 500$ pesos for his denunciation and $\$ 1,000$ pesos for the capture of "el Emisario del abominable Napoleon." 33

"Day and night patrols should disperse meetings of suspicious and vice-ridden persons, confiscate their arms and offensive material. Sedi-

29 Ibid., p. 834.

${ }^{30} \mathrm{Ibid}$., p. 836.

${ }^{31}$ De Vos, 1994: 246-247.

32 Circular, Bustamante, November 8, 1811.

33 Ibid.

Instituto de Investigaciones Filológicas/

Centro de Estudios Mayas, UNAM

ISSN: 0185-2574 
tious filiers etc. should be turned over to authorities without reading or copying them."34

In 1812 the insurgents were threatening from the north, but the hacienda owners were even more afraid of the Indians. The Archbishop sent his views to the Bishop: "Parece que algunos de tales insectos habian asomado p.r la raya de Tabasco. Es el mejor remedio, el exterminar las primeras partidas de vandaleros, antes q.e empiezan a alborotar unos tras otros los Pueblos." ${ }^{35}$

And everyone was waiting for the news of the death toll of the "gabachos" killed in the latest battles in Spain fought three months before, as well as news of the constitutional debates in the Cortes.

The Indians were asked to demonstrate their love and loyalty to the king by providing a contribution.

This is not a purely voluntary act, it is an obligation of conscience and justice [...] Indians are relieved of tribute, but not of the debt of vassals [...] It is a very great difference that they give voluntarily, what before was demanded rigorously, but it should not be less, rather more, if possible, for the great need, in thanksgiving for such a singular benefit and since the quota of 2 pesos is so moderate [...] In other parts Ladinos were tributaries like the Indians. They never have been in this district. ${ }^{36}$

A priest responded to the plea for a 3 pesos donation, saying, "Todos son unos pobres que apenas alcanzan para comer. Estoy enfermo pero lo doy. ${ }^{37}$ In 1805 the government reported that the Indians

\footnotetext{
${ }^{34}$ Decreto, Bustamante, December 23, 1811.

35 Carta de Casaús a Llano, Agost 3, 1812.

${ }^{36}$ Decreto, Bustamante, April 10, 1812.

${ }^{37}$ Carta de un padre (?), May 24, 1812.

${ }^{38}$ Ayuntamiento de Ciudad Real, January 22, 1805.

39 Carta, capitulares a Llano, December 21, 1812.

${ }^{40}$ Carta, Llano a los capitulares, December 21, 1812.
} Estudios de Cultura Maya. Vol. XXI, 2000 tienen reducidas las sementeras, aun de aquellas semillas, que son de primera necesidad a un estado tan deplorable, que es mas digno de lagrimas, que de ponderacion y por mas que se exagere, nunca se podra hacer una pintura al vivo del miserable estado, en que se hallan los naturales del País...Ocio y Embriaguez, ${ }^{38}$

\section{as always, are reported.}

With Morelos' army threatening to invade Chiapa brigades of Honorary Volunteers were established, but shortly after the new Constitution was celebrated the church authorities addressed the Bishop:

Hemos visto con nuestros propios ojos, salir de esta Ciudad a las acongajadas ovejas de VSI no como Leones feroces, animados de los ecos de los clarines belicos, sino como mansos corderos que llevan atados al matadero. Hemos puesto a disposicion de este Gobierno, para las urgencias de la defensa de la Corona, y la Patria, en la invasion que amenaza, los caudales de la Iglesia, sus alhajas, nuestras rentas, y nuestras propias personas. ${ }^{39}$

\section{The Bishop praised them for being}

movidos de caridad, humanidad, y Patriotismo, y usando del dro. de Ciudadanos con q.e los distingue la nueva constitucion, a una voz, de improviso, y unanimos resolvieron manifestar el desaliento, temores, y amarguras q.e padece este fidelismo, y pasifico Pueblo, con las circunstancias criticas del motivo de q.e acordamos del mismo modo, poner a disposicion del Govno. todos los caudales, y Alajas de esta sta. Iglesia, de q.e soi indigno Esposo. ${ }^{40}$ 
Shortly after, Morelos' general, Matamoros, on the coast of Chiapa, with 195 of his choicest men, put to flight Guatemala's army of 2200 soldiers, mostly black ex-slaves from Honduras. Their general, the Italian, Dambrini confessed that they wanted to be home with their families. The victor, Matamoros, pledged to the people of Tonala that his men were not what Dambrini's soldiers had claimed, “...judíos, que saqueaban, forzaban a las mujeres, les cortaban los pechos, mataban a los niños y después de muertos los cargaban ensartados en las bayonetas."

The Bishop, a man of integrity to whom both liberals and conservatives confided, was advised by the governor to flee. On the very day of his departure

un cierto Sacerdote, creyendo que teniamos ya al enemigo en la plaza, ensilló su caballo y saliendo precipitadamente a fuga, iba por las calles repitiendo a gritos: Que bacen, que no buyen. Con esto, las gentes huyeron a los montes, dexando abandonadas sus casas y aquella noche tocarron los Sanganos a zaqueo. Tolerable mal era perder los bienes, sino se huviesen seguido abortos, y aun se dice que muertos. Muchas casas se mantienen abandonadas, sin saberse el paradero de sus dueños. ${ }^{42}$

But even worse, the Archdeacon learned that the nuns wished to recant, so he had the convent bell rung " $y$ a las que se hiciense del partido de los Insurgentes, desde aquel momento las declaraba yo Apostatas y les prometia tratarlas como tales." ${ }^{13}$ The Abbotess protested that she knew she had made a mistake, that she had been triked and would not leave the faith.

But at least Don Ambrosio had received a letter from the Capuchin Abbotes of Nueva Goathemala addressed to him as "Mui Estimado Sr. y Tatita de mi Corazón", and closing with "Maria Coleta Indigna Abadesa" where she sent passionate wishes for his safety and in a postscript advised him that the "Negro Macario" would bring him "esos jabonsillos p.a la barba" 44 that hopefully arrived in time for his hasty departure.

Meanwhile, in Cadiz the deputy of Chiapa, Mariano Robles, was describing to the Cortes the plight of the Indians:

He places in sharp contrast the behavior of the Spanish political leaders and their Indian subjects. The first, godchildren, servants or cronies of the President, are elected regadless of whether they are "inepto o de mala vida o costumbres." ${ }^{15} \mathrm{He}$ describes in detail their exploitation of the Indians, who address them with "un miedo tan servil como odioso," on bended knee, with uncovered head, referring to them as "Rey." 46 Viewing the activities of these Spaniards "no podremos ménos de llenarnos con indignación," ${ }^{17}$ for in this rich land they have reduced the population to extreme poverty, virtual slavery.

Robles tells how his colleague, Fernando Dávila, later his successor in the Cortes, came to him just before his own departure for Spain, "con los ojos bañados en lágrimas," scribed how one of his Indian parishioners had

\footnotetext{
${ }^{41}$ De la Fuente, 1913: 49

${ }^{42}$ Carta, Ordónez y Aguiar a Llano, May 6, 1813.

43 Ibid.

44 Carta, Coleta a Llano, April 26, 1813.

45 Núñez de León, 1992: 11.

46 Ibid., p. 12.

47 Ibid., p. 15.

48 Ibrducposize Cultura Maya. Vol. XXI, 2000

Instituto de Investigaciones Filológicas/

Centro de Estudios Mayas, UNAM 
collapsed under a 200 pound load of indigo. "Yo mismo, Señor, me he enternecido muchas veces al verles subir por aquellas penosas cuestas desnudos y vañados en sudor; $y$ al oir sus lastimos quexidos en fuerza de su fatiga, no ha podido menos de conmoverse y afligirse mi espíritu." ${ }^{49}$ He tells of "la bárbara inhumanidad con que se les trata." 50 If they have not died from exhaustion, thirst, hunger, from the change of climate, or from sickness after fording rivers, it is most likely that their return journey, also heavily loaded, will bring them home only to sicken and die.

Viven toda la vida llenos de agitación, y en continuo terror y sobresalto; porque llega a tal grado el desprecio y odio, con que se les trata, que no hay cochero, lacayo, ni hombre ruin, hasta el mismo verdugo, que no se crea autorizado para maltratarles publicamente, en vista del mal exemplo y de la suma crueldad con que les tratan, especialmente otras personas de carácter, y de superior esfera, azotándoles y dándoles de bofetadas o palos. ${ }^{51}$

¿Es posible que haya habido quien les creyese punto menos que brutos, y aun les negase temerariamente la racionalidad? Nada tiene de extraño, porque como de estas cosas sabe figurarse la negra envidia, y la insaciable ambición. ${ }^{52}$

As for their education by the Spaniards:

$\mathrm{Y}$ aunque es verdad que en ciertos pueblos hay algunos con el nombre de maestros, asalariados con los bienes de comunidad de los Indios, regularmente son personas ineptas y tan ignorantes, que apenas saben leer, y lo que es mas lastimoso de mala conducta, y entregados a la embriaguez; los quales entreteniéndose con tres o cuatro pequeños Indios, y sirviéndose de ellos para varios encargos propios u oficios domésticos, nada les enseñan; pues apenas aprenden la cartilla despues de tres o quatro años, por lo que se retraen sus padres de embiarles a sus escuelas, al paso que los Españoles pobres y otros carecen de todo auxilio para la enseñanza de sus hijos, quienes van al sepulcro con la misma ignorancia que nacieron; en cuya confirmación basta decir que el cabo de tres siglos, no hablan los Indios el Castellano. ${ }^{53}$

Robles wrote to Bishop Ambrosio about his attempts to secure authorization for a university in Chiapa and scholarships for 12 Indians. His request was approved by the Cortes so long as the proposal was economically feasible and so long as the funds for the scholarships came from the Indian communities. He exclaimed to the President of the Cortes, "Viendo que se atropellan sus imprescriptibles derechos con escandalosa infraccion de la misma Constitucion politica [...] cual es la libertad [...] continuan arrastrando sus mismas cadenas sin poder salir de su vergonzoso estado." 54

Let us now take a brief look at how the friar remodeled the proclamation for his Indian audience. He tripled its length so that it would take an hour to read from the pulpit. While the original proclamation mentioned the heart and the eye but once, the Tzolzil had 39 hearts and 19 eyes along with 27 souls. In the original there were 13 references to body parts while in the Tzotzil 155. In the original there were 2 fathers, 1 mother and 2 sons. In the Tzotzil 29 fathers, 23 children and 11 mothers along with 11 elder brothers. In the original there was not a single reference to natural and supernatural phenom-

\footnotetext{
49 Ibid.

so Ibid., p. 14.

51 Ibid., p. 14-15.

52 Ibid., p. 9.

53 Ibid., p. 20.

54 Berruezo, 1986: 208.
} 
ena while in the Tzotzil 62, with God appearing 23 times.

For the friar this was not simply a political document, but a moral document. The original had but 4 such terms, while the Tzotzil had 87 , with 36 references to goodness and 24 to evil.

The friar, clearly not a native speaker, but with a sophisticated knowledge of its grammar and expression, had struggled with the "tan dificil traduccion" 55 of the Proclamation so that its elevated tone would be conveyed to the Indians and simultaneously reach their hearts - a task he carried out loyally, weaving an elaborate tapestry of metaphor, bedizened with horned serpents, whirlwinds and jaguars, and yet a task that this conservative priest, believing in the divine right of kings, must have performed with deep misgivings.

We can dare to surmise about the general historical significance of the Proclamation of 1812 , but locally we are without a clue. If the Tzotzil proclamation was ever read in the churches, if it won the Indian parishioners' loyalty to the Metropolis and gave them a new sense of self-respect, for this we have no evidence. The return of the absolutist Fernando VII, no longer El Deseado, but now known as Narizotas, ended all hopes.

While there are Tzotzil word lists, grammars, catechisms, and sermons from the 19th century, this is a unique survival of Tzotzil narrative from that period. There are no earlier narratives of any length. The mixture of Tzeltal with the Tzotzil is puzzling. Perhaps it was a deliberate ploy of the anonymous priest so that his translation would reach the speakers of both languages.

There is no way to judge from the available historical records what the significance of the
Proclamation was in the nineteenth century, either nationally or locally, but in company with contemporary decrees and correspondence, it opens a window on the years just prior to independence; a chapter of Spanish, French, and local Chiapas history that has been allowed to slumber on the shelves. Who of us would dream that for the officials of that time Napoleon and his spies were like the "red scare?" This was a period of high hopes, of dark intrigues, of failed aspirations, when Church and State worked at times in union and at times in great conclict, when the general public celebrated in Spain and in America the birth of the Constitution, and two years later, with equal gusto, its premature death. In the foreground strutted Napoleon and Joseph Bonaparte, who had awarded himself Spain's highest honor, the Golden Fleece, in combat with Lord Wellington. Just behind stood Fernando VII, the Prince of Peace, Alexander of Russia, "los viles insurgentes," 56 "los sabios"57 of Cadiz, Archbishops, Bishops, Captains general, and an anonymous priest all imploding on the lives of the Tzotzil Mayan Indians of the Province of Chiapa. Or maybe not.

Eighty one years have passed. For the first time since 1527 the Indian merchants of Hidalgo and Oaxaca have been prohibited by the mayor of Cholula in the state of Puebla to sell their handicrafts at the patron saint's fiesta because he did not want "animalitos" in the streets.

The parallels between the figures and events of Chiapa in the early nineteenth century and in Chiapas today are amazing.

In Chamula, as in the 1780 s, the Indian caciques, supported by the government, refusing that their people be catechized, have run the priest out, and caused many Chamulas to flee to San Cristobal.

\footnotetext{
55 Sotzil: portada.

${ }^{56}$ Carta, Llano a Bustamante, May 17, 1813.

57 Sotzil: 15.

Estudios de Cultura Maya. Vol. XXI, 2000

Instituto de Investigaciones Filológicas/

Centro de Estudios Mayas, UNAM 
Just as in 1812 the Bishop has been a significant moderator between the conservatives and the liberals.

Then and now there was a goverment representative who strove to gain rights for the Indians (Mariano Robles, Manuel Camacho). Then as now, a conservative church official working against the Bishop (the Archdeacon and the Papal Nuncio). Then as now, an eloquent revolutionary military leader (Matamoros and Subcomandante Marcos). Then as now, bands of ill-armed insurgents lurking in the woods.

Like our friar, Subcomandante Marcos has absorbed the Mayan metaphors, saying "Somos la montaña;" "Somos la gente de la noche, los tzolziles, los murciélagos."

And in January, 1994 as the Zapatistas approached Zinacantan it was reported that a giant serpent rose up in the sky and a thunderbolt crashed down. They fled to Chamula where a giant serpent rose up in the sky and a thunderbolt crashed down, so they fled to San Andres Larrainzar, where they are today.

But in June the story had shiffted: After the shamans prayed for protection in the mountains, when the Zapatistas approached town a giant serpent rose up and a whirlwind carried off their headgear and they fled. Then the federal soldiers approached town, a giant serpent rose up and a whirlwind chased them away.

This is history. Believe it or not!

\section{Bibliography}

AGE $=$ Archivo General del Estado, Tuxtla Gutiérrez. $\mathrm{AGN}=$ Archivo General de la Nación, México, D. F.

$\mathrm{AHD}=$ Archivo Histórico Diocesano de San Cristóbal de Las Casas.

$\mathrm{INAH}=$ Instituto Nacional de Antropología e Historia, México, D. F.

$L C=$ Library of Congress, Washington, D. C.
Berruezo, María Teresa

1986 La participacion americana en las Cortes de Cádiz 1810-1814, Centro de Estudios Constitucionales, Madrid.

Boletín del Archivo General del Gobierno

1938 Guatemala City, 3 (2, 3, 4), 4 (1).

CARR, RAYMOND

1966 Spain 1808-1939, Clarendon Press, Oxford.

De Vos, Jan

1994 Vivir en frontera: La experiencia de los indios de Chiapas, Historia de los pueblos indigenas de México, Centro de Investigación y Estudios Superiores en Antropología Social, Instituto Nacional Indigenista, Mexico.

\section{Gazeta de Guatemala}

1810 vol. XIV, Guatemala City.

Hernández Y Dívalos, Juan

1877 Colección de documentos para la bistoria de la guerra de independencia de México de 1808 a 1821, 2 volumes, vol. II, Impr. J. M. Sandoval, México.

NúNez de LEón, Rodrigo

1992 Memoria Histórica de la provincia de Cbiapa, una de las de Guatemala, Rodrigo Núñez, editores, Tuxtla Gutiérrez.

Porrún, Miguel Ángel (ed.)

1992 Autos seguidos por algunos de los naturales del pueblo de Chamula en contra de su cura don José Ordónez y Aguiar por varios excesos que le suponian 1779 , Gobierno del Estado de Chiapas, Universidad Autónoma de Chiapas y Facultad de Derecho de la unam, Mexico.

Rivet, Paul, and Georges de Créqui-Montfort

1951 Bibliograpbie des langues aymará et kichua, Institut d'ethnologie, Université de París, París, Travaux et mémoires de l'Institut d'ethnologie, 51, 4 volumes, vol. 1.

Stanhope, Philip Henry, 5th Earl of

1888 Notes of Conversations with the Duke of Wellington, 1831-1851, John Murray, London.

Vela, David

1956 Barrundia ante el espejo de su tiempo, Editorial Universitaria, Guatemala.

WaLTON, WILLIAM

1814 Exposé on the Dissentions of Spanish America, Booth, London. 


\section{Circulars, Decrees and Reports}

Circular, José de Bustamante Guerra de la Vega, Rueda, Cobo, Estrada, y Zorlado, 8 November, 1811, AGE; Serie Chiapas rollo 90.

Decree, José de Bustamante, 23 December, 1811, AHD. 10 April, 1812, AHD.

Report, Ayuntamiento de Ciudad Real, 22 January, 1805, INAH; t. II, doc. 13.

\section{Proclamations}

"Proclama del Arzobispo Virey de México, contra los engaños pérfidos de los Bonapartes", Mexico City, 24 April, 1810, AGN; Impresos Oficiales 30: 53-63, LC.

"Sotzil", Princeton University Library, the Garret Collection of Middle American Mss., 254.

\section{Letters}

Capitularies to Ambrosio Llano, 14 December, 1812 , AHD.
Casaús y Torres, Ramón, to Ambrosio Llano, 3 August, 1812, AHD.

Coleta, María, to Ambrosio Llano, 26 April, 1813, AHD.

Gates, William, memorandum list $\mathrm{n}^{\circ} 7$ to Carles Bowditch, 1915 (?), Princeton Univesity Library, The Garrett Collection of Middle American, Mss. 254.

Llano, Ambrosio to José de Bustamante, 17 May, 1813, AHD. To capitularies, 21 December, 1812, AHD.

Ordóñez y Aguiar, Ramón, to Ambrosio Llano, 6 May, 1813, AHD.

Polanco, Francisco, to Carlos III, 20 May, 1778, AGE; Serie Chiapas rollo 69.

Priest of ?, to Ambrosio Llano, 24 May, 1812, AGE; Serie Chiapas, rollo 90.

Note: I cannot find the Spanish original, for quotations $10,19,21$, and for quotations 34,36 , wich I do not have at hand, they can be found in the Archivo Histórico Diocesano. 